\title{
Cryptic variation, molecular data, and the challenge of conserving plant diversity in oceanic archipelagos: the critical role of plant systematics
}

\author{
Daniel J. Crawford* and Tod F. Stuessy ${ }^{1}$ \\ Department of Ecology and Evolutionary Biology and the Biodiversity Institute, University of Kansas, Lawrence, KS 60045, USA \\ ${ }^{1}$ Herbarium, Department of Evolution, Ecology, and Organismal Biology, The Ohio State University, 1315 Kinnear Road, Columbus, \\ OH 43212, USA, and Department of Botany and Biodiversity Research, University of Vienna, Rennweg 14, A-1030 Vienna, Austria
} (Received 6 May 2016; Accepted 24 May 2016)

\begin{abstract}
Plant species on oceanic islands comprise nearly $25 \%$ of described vascular plants on only $5 \%$ of the Earth's land surface yet are among the most rare and endangered plants. Conservation of plant biodiversity on islands poses particular challenges because many species occur in a few and/or small populations, and their habitats on islands are often disturbed by the activity of humans or by natural processes such as landslides and volcanoes. In addition to described species, evidence is accumulating that there are likely significant numbers of "cryptic" species in oceanic archipelagos. Plant systematists, in collaboration with others in the botanical disciplines, are critical to the discovery of the subtle diversity in oceanic island floras. Molecular data will play an ever increasing role in revealing variation in island lineages. However, the input from plant systematists and other organismal biologists will continue to be important in calling attention to morphological and ecological variation in natural populations and in the discovery of "new" populations that can inform sampling for molecular analyses. Conversely, organismal biologists can provide basic information necessary for understanding the biology of the molecular variants, including diagnostic morphological characters, reproductive biology, habitat, etc. Such basic information is important when describing new species and arguing for their protection. Hybridization presents one of the most challenging problems in the conservation of insular plant diversity, with the process having the potential to decrease diversity in several ways including the merging of species into hybrid swarms or conversely hybridization may generate stable novel recombinants that merit recognition as new species. These processes are often operative in recent radiations in which intrinsic barriers to gene flow have not evolved. The knowledge and continued monitoring of plant populations in the dynamic landscapes on oceanic islands are critical to the preservation of their plant diversity.
\end{abstract}

Keywords: conservation, cryptic diversity, island plants, molecular data, plant systematics

Although oceanic islands have long been known for their unusual animals such as the giant tortoises in the Galápagos Islands, many island plants are very distinctive morphologically from their continental relatives, with the silversword alliance of Hawaii perhaps the best-known example (Carr, 1985). Insular endemic plant lineages are often characterized by: occurrence in different habitats; striking morphological differences among species; and their frequent rarity, being present in a few small populations. Islands account for only about $5 \%$ of the land surface of the Earth, yet, by current estimates, insular endemics account for almost $25 \%$ of described vascular plant species (Kreft et al., 2008). It has been estimated that 5 to $10 \%$ of the insular endemics worldwide could be highly threatened and that 3 to $4 \%$ could be in critical danger of extinction (Caujapé-Castells et al., 2010).

The conservation of endemic island plants is a complex, multifaceted topic, including the preservation of native habitat, control of alien plants and animals, and minimizing the impact of human activities (Caujapé-Castells et al., 2010). While these factors are very important, the present paper focuses on the

\footnotetext{
*Author for correspondence: dcrawfor@ku.edu
} 
role of systematists in the conservation of biodiversity within island plant lineages. In the present discussion, plant systematics will be used in a broad sense to include traditional taxonomy with the naming and identification of species based on morphology, experimental biosystematics, reproductive biology such as breeding systems and pollinators, use of molecular markers and phylogenetic reconstruction.

Island plant biodiversity can be viewed at several hierarchical levels, but the species is commonly recognized as the fundamental unit of biodiversity both from the view of the scientific and lay communities (Steele and Pires, 2011). Importantly, species and subspecific recognition are the basis for legal protection of plants by the United States Endangered Species Act, although other agencies may include consideration of "distinct" populations (Allendorf et al., 2013, pp. 317, 318). The issues of species concepts and/or criteria for recognizing species have been and continue to be discussed and debated (e.g., Mallet, 1995; Mayden, 1997; de Queiroz, 1998; Hausdorf, 2011), and will not be considered in detail. Rather, the topics will be dealt within the context of island plants. The traditional morphological/typological species concept/criterion, if not explicitly stated in taxonomic treatments and the description of new species, is most commonly employed by plant systematists.

Despite the importance of species in biodiversity studies, particularly within island archipelagos, understanding population variation within species is also critical to the conservation of genetic diversity. This is true because individual or groups of populations may represent cryptic species that could go undetected with the types of data often employed in systematic studies. Whether or not recognized taxonomically, the detection of variation within recognized taxa is important because it calls attention to the value of conserving diversity and adaptive/evolutionary potential. Since there is no universally accepted species definition, it follows that there is no generally agreed upon definition of cryptic species; in the present paper the working definition will be that "they are at least superficially morphologically indistinguishable" (Bickford et al., 2006, p. 149). For vascular plants, casual observation with the naked eye, or with $10 \mathrm{x}$ or lower magnification could be classified as "superficial" examination. Sibling species are sometimes further distinguished from cryptic species in that they are sister species (Bickford et al., 2006). Cryptic species are likely, but not inevitably, sister species because their morphological similarities are the result of recent divergence from a common ancestor in the island setting.

We will discuss some challenges of documenting biodiversity in the flora of oceanic islands, with emphasis on the discovery of cryptic diversity and the issues involved in recognizing the diversity taxonomically. The discussion will be centered on species and subspecies, but will also consider the conservation of diversity at the population level within species. In addition to morphology, the use of molecular markers for detecting cryptic diversity and for informing taxonomic decisions will be reviewed, and this will bring into play a discussion of the genotypic cluster definition of species (Mallet, 1995). We will highlight the roles of present and emerging molecular/genomic data in the study of cryptic diversity in insular plant lineages. At the same time, emphasis will be placed on the importance of traditional taxonomic studies to complement information from genetic/genomic data in the conservation of oceanic island floras. Discussion of molecular phylogenetic studies of island plant lineages will provoke comments on the conservation of phylogenetic diversity (Diniz-Filho et al., 2013; Winter et al., 2013). We will argue that only collaborative studies between systematists and workers in other disciplines will achieve the necessary integration of data for conservation purposes.

\section{Field studies: observations and collections}

Because oceanic islands are relatively small areas that are clearly delineated by their isolation in vast oceans, it might be tacitly assumed that extensive collecting has been done in all areas of islands and that insular floras are well documented. Despite extensive fieldwork on many archipelagos, new plant taxa are constantly being described (e.g., Ferreira et al., 2014; Puppo, 2015). In some instances, novelties have been found in very inaccessible areas (Funk and Wood, 2014). In other cases, species occur in easily accessible areas, and intensive field studies provided insights into variation in several "cryptic" morphological features that are maintained in cultivation in a uniform environment (e.g., Crawford et al., 2013). The value of field observations over several years cannot be overstated for detecting cryptic diversity because good field taxonomists come to recognize subtle (cryptic) differences among populations of what are considered the same species. This was the case in the description of the new species Tolpis santosii (Asteraceae) from the Canary Islands, which was based on the perceptive observations of Arnoldo Santos-Guerra over many growing seasons (Crawford et al., 2013). In some instances, critical study of herbarium material and expanded field studies that augment scant herbarium material have resulted in the resurrection of species previously placed in synonymy (Senterre et al., 2015). These cited studies, along with many others, suggest that intensive field studies, including special collecting efforts in poorly explored areas of islands and critical 
examination of herbarium specimens by plant systematists, are critically important components in the discovery of cryptic variation in island floras. Particular challenges may include both getting to remote islands and doing fieldwork in inaccessible parts of islands.

In addition to islands of different ages in archipelagos such as the Canary and Hawaiian Islands, there are substrates of varying ages on single islands, as well as areas of natural and human-mediated disturbances on individual islands (e.g., Sherrod, 2009; Carracedo, 2011). In essence, there may be islands within islands, with species or cryptic species, occurring on different substrates on islands with complex geological histories, such as Tenerife in the Canary Islands (e.g., Puppo et al., 2014). More recent lava flows (even in historical times), natural landslide areas, and areas of human disturbance provide open areas for colonization and subsequent divergence, as well as the potential for the generation of novelty by hybridization (Otto et al., 2016). Field studies of plant lineages occurring on the variety of substrates on oceanic islands are important in detecting cryptic diversity within lineages.

\section{Reproductive biology}

It goes without saying that the persistence, diversification and speciation of plants in oceanic archipelagos depend on successful sexual reproduction (Anderson et al., 2001; Bernardello et al., 2001; Crawford et al., 2011). As colonizing plants adapt to the island setting, cryptic diversity in floral traits may occur and these plants may "break the rules" relative to the expected associations of floral features and breeding systems. For example, in the Juan Fernandez Islands, the endemic, monophyletic composite genus Dendroseris (or Sonchus subgenus Dendroseris; Mejías and Kim, 2012) has both self-incompatible (SI) and self-compatible (SC) species (Anderson et al., 2001; Bernardello et al., 2001). However, the SC species still retain the floral characters typical of SI outcrossing species instead of having evolved the reduced size and number of floral parts typical of the so-called "selfing syndrome" (Ornduff, 1969; Slotte et al., 2012, see below). Another excellent example of island plants "making do" for sexual reproduction comes from Robinson Crusoe island in the Juan Fernandez archipelago. Anderson et al. (2000a) showed that in the endemic species Wahlenbergia berteroi (Campanulaceae) elongation of the styles carries pollen near the throat of the corolla and rubs against the inner surface of the corolla. Wind shaking the flowers brings the pollen on the inner surface of the corollas in contact with the receptive stigmata, which effects pollination. It is clear from these two (and many other) examples that breeding systems in island plants may be cryptic because superficial observation of floral morphology suggests that they are typical of outcrossing species even though they have the ability to self. Field studies determining whether isolated flowers (bagged to exclude pollen from other plants), with and without manual self-pollination, can set seed, will show whether plants are SC and further whether they can efficiently self-pollinate or require a pollen vector. There are important conservation implications of the breeding systems of island plants and whether pollen vectors are needed (Anderson et al., 2001; Bernardello et al., 2001). These include genetic diversity within and between populations (e.g., Hamrick and Godt, 1997) and whether seed set is limited by lack of pollinators or compatible mates (in the case of SI plants, see below), especially in the small populations typical of oceanic islands (Pannell, 2015). Even more subtle and cryptic are island plants that are basically SI but are "leaky" and allow some self seed set (e.g., Nielsen et al., 2003; Crawford et al., 2015). Presumably, this system assures some seed set while retaining the genetic diversity of an outcrossing breeding system (Levin, 1996).

Another form of cryptic diversity in the reproductive biology of island plants is the early stages of the evolution of dioecy (the separation of the sexes on different plants) (e.g., Sun et al., 1996; Anderson et al., 2000b, 2006). In fact, flowers may be functionally unisexual yet have both stamens and gynoecia, and casual observation could easily lead to their interpretation as bisexual flowers; the ease of detecting differences will depend on morphological similarity of the nonfunctional and functional forms in the different sexes. Detecting cryptic functional dioecy is important in the conservation of island plants because if the ratio of male and female plants becomes skewed, as could be the case in small populations, it would have an effect on seed set and on genetic diversity within populations because it reduces the effective population size (Allendorf et al., 2013, chapter 7). Dramatic examples of the extinction of dioecious species in an oceanic archipelago in historical times are provided by two very distinctive species from the genus Robinsonia (Asteraceae), R. macrocephala and $R$. berteroi, from the Robinson Crusoe Islands. For several decades, the latter species was known from only a single male plant (Stuessy et al., 1998a,b) and it is now thought, like $R$. macrocephala, to be extinct (Danton et al., 2006).

\section{Molecular markers}

Molecular data have been employed extensively in the study of island plants, with the results often discussed in terms of conservation implications. Allozymes, which are inherited as co-dominants, were the first molecular markers employed in 
assessing genetic diversity within and divergence among species of island endemics (Lowrey and Crawford, 1985; Crawford et al., 1987; Witter and Carr, 1988; de Joode and Wendel, 1992). However, allozymes often lack the variation necessary to distinguish morphologically distinct insular congeneric species (Lowrey and Crawford, 1985; Helenurm and Ganders, 1985; Francisco-Ortega et al., 1996a). Exceptions include Witter and Carr (1988) and Kim et al. (1999) where higher divergence was seen between species from older than between species on younger islands in an archipelago. The rapid and recent divergence of insular species relative to mutation rates at allozyme loci (Schlötterer, 2004) and the relatively small number of loci typically resolved are factors in the lack of resolution of morphologically distinct species. These factors would seem to further limit the utility of allozymes for the identification of cryptic species. Despite generally low variation, allozyme data have been used to assess diversity within and among conspecific populations, and to correlate patterns of variation with various life history and other biological traits; these data may be used to inform strategies for the conservation of genetic diversity (Francisco-Ortega et al., 2000; Crawford et al., 2001; Pérez de Paz and CaujapéCastells, 2013).

Following allozymes, several types of anonymous PCRbased DNA markers, such as random amplified polymorphic DNA (RAPD), inter-simple sequence repeats (ISSR), and amplified fragment length polymorphism (AFLP), have been employed for assessing genetic diversity in plant species (Nybom, 2004; Schlötterer, 2004; Bonin et al., 2007; Meudt and Clarke, 2007). All three markers are inherited as dominants. They have been applied widely to studies of diversity in island plants, including variation within species (e.g., Brauner et al., 1992; Crawford et al., 2001), subspecies (Caujapé-Castells et al., 2008) and populations (Archibald et al., 2006). The extensive ISSR study of Canary Island Tolpis by Archibald et al. (2006) showed the potential of these markers for distinguishing species because they did resolve morphologically distinct clusters of populations recognized as species, and several populations identified as cryptic species based on morphology and geographic distribution were distinct. The RAPD marker study by Caujapé-Castells et al. (2008) is an excellent example of congruence between molecular markers, morphology, and geographic distribution for recognizing subspecific taxa. In general, these three dominant markers are of greater utility than allozymes in distinguishing species or detecting cryptic diversity because they are more variable than allozymes (Freeland et al., 2011, p. 71) and many more loci can be resolved than with allozymes. One of the potential problems with the use of PCR-based DNA markers, especially RAPDs, but ISSRs as well, is the reproducibility of the results, and replicate runs should be done to document that results can be duplicated (Schlötterer, 2004).

Microsatellites or simple sequence repeats (SSR) have enjoyed more recent popularity than the three dominant molecular markers because they are inherited as co-dominants, which, like allozymes, have distinct advantages in the kinds of analyses that can be done and the kinds of insights that can be obtained (Freeland et al., 2011). A limitation of the use of SSRs has been the effort and expense of designing primers for the taxa of interest, as there are no universal primers as with RAPD or ISSR primers. However, continuing development of next-generation sequencing technologies make the isolation of SSR loci ever more cost efficient (Takayama et al., 2011, 2013; Zalapa et al., 2012), and the markers have been used in studies of island plants (e.g., Friar et al., 2007; López-Sepúlveda et al., 2014; García-Verdugo et al., 2015). Silva Borges et al. (2016) provided an illustration of the utility of SSRs for detecting cryptic diversity in what has been treated as one endemic species in an oceanic archipelago. Specifically, several different analytical methods showed three major genetic groups within Tolpis azorica that correspond to populations from different geographical groups of islands in the Azorean archipelago. However, Silva Borges et al. (2016) caution that intensive morphological studies are needed to further evaluate whether the different genetic groups identified by SSR markers are worthy of further consideration for taxonomic recognition. It should be mentioned that data from markers such as allozymes and PCR-based DNA markers are frequently subjected to analyses that produce estimates of similarity or distances among populations of the same and different taxonomic entities rather than in qualitative differences, although, the presence/absence of private (unique) alleles are sometimes reported and would represent a character based approach (see below).

The use of short DNA sequences, so-called barcodes, has been of interest, discussion and debate for the taxonomic identification of specimens that are insufficient for identification from morphological characters, for the detection of cryptic species, and for application to the conservation of plant biodiversity (Kress et al., 2005; Hollingsworth, 2008). Discussion has centered on practical aspects such as the utility of different sequences as barcodes and the rationale for using the approach (Blaxter, 2004; Hajibabaei et al., 2007; Thompson and Newmaster, 2014). Distance measures of sequence divergence and/or character based differences with one or more diagnostic positions in sequences (CBOL Plant Working 
Group, 2009) have been employed in barcoding studies.

Rapid morphological divergence during the radiation of insular lineages, as discussed above, would seemingly present a rather formidable challenge for use of DNA barcoding. As mentioned above, even morphologically distinct congeneric species in insular radiations are often not well differentiated with allozymes and other molecular markers, further suggesting that they could offer a rigorous test for DNA barcoding. Presumably, the task would be even more difficult for detecting cryptic variation within species given that morphologically distinct species may not be distinguishable. The genus Tolpis in the Canary Islands would seemingly present a rigorous test for DNA barcoding because nuclear ITS and several plastid sequences were of limited value for distinguishing some morphologically distinct taxa, in resolving relationships among taxa, and in distinguishing cryptic taxa suggested from morphology (Mort et al., 2007; Gruenstaeudl et al., 2013). Mort et al. (2010) used a character-based approach (presence of diagnostic sequences) with two different combinations of four plastid sequences as barcodes for distinguishing both morphologically distinct as well as several morphological forms not recognized taxonomically. The results were somewhat "mixed" in that several morphologically distinct species were distinguishable, whereas the most morphologically divergent species in the Canary Islands was not novel with either barcode combination. By contrast, certain morphological forms (cryptic species?) were distinct. Because sampling was limited in this study, and two of the most common and variable species have been shown to be polyphyletic (Mort et al., 2015, see below), it is difficult to draw strong inferences about the value of the plastid sequences as DNA barcodes for Tolpis in the Canary Islands. Additional sampling, particularly of cryptic morphological diversity, would be needed to assess the performance of barcoding.

Schaefer et al. (2011) used nuclear ITS sequences (so-called ribotypes) and plastid sequences essentially as barcodes to examine variation in single species in several lineages within the Azorean archipelago. Plastid data were invariant within each of the species whereas variation in ITS ribotypes was found in seven of the eight species examined. Furthermore, within the seven variable species, $71 \%$ of the ITS ribotypes were restricted to single islands. Thus, in sharp contrast to the current taxonomic treatment in which single species are recognized as occurring over several islands in the Azorean archipelago, the molecular data raise the possibility of several single island endemics. Schaefer et al. (2011) emphasized that the Azorean endemic flora is poorly known morphologically, and that critical study is needed to increase the understanding of the evolution of the flora and to inform conservation decisions. They called for "a thorough and critical re-evaluation of the morphological variation in the endemic flora" (Schaefer et al., 2011, p. 1352), which is the domain of plant systematists. It is interesting that, while molecular marker studies have been done on these species, basic taxonomic work is lacking. The results of Schaefer et al. (2011) parallel those of Silva Borges et al. (2016) cited above for Azorean Tolpis in which molecular data indicated clusters within the single endemic species $T$. azorica, and suggest that the Azores could harbor much cryptic diversity. In this regard, it is interesting to note that an intensive morphological study of Vaccinium cylindraceum (Ericaceae) by Pereira (2008) indicated differences among populations from different islands in the Azores, and provides additional evidence that basic taxonomic studies are needed to elucidate cryptic diversity in the archipelago.

Schaefer et al. (2011) noted that while the ITS ribotypes showed geographic structure, they did not distinguish ecological variants within the species, and the authors suggested that geographical divergence occurred before the much more recent ecological divergence. Jones et al. (2014) found examples within the Macaronesian endemic genus Pericallis (Asteraceae) in which molecular data did not distinguish morphological/ecological variants within species, and other instances in which molecularly distinct populations were not obviously separable by morphological traits. Jones et al. (2014, p. 646) opined that their results "merit further taxonomic work." The results of both Schaefer et al. (2011) and Jones et al. (2014) illustrate the need for extensive field studies by plant systematists in order to elucidate morphological and habitat variation for single endemic species, which would be of value for informing conservation decisions in the Azorian archipelago.

Jaén-Molina et al. (2014) conducted a recent barcoding survey of 45 species, 12 subspecies and three varieties of flowering plants endemic to the Canary Islands. They employed both distance and character based analyses (see above) as distinguishing criteria. Their results showed that sequences from two regions of the plastid genome distinguished over $80 \%$ of the congeneric species that are morphologically similar but clearly distinguishable. The barcode sequences resolved between 21 and 37 percent of the cases (depending on the criteria employed) where species, subspecies or populations are difficult to identify based on "available morphological characters" (Jaén-Molina et al., 2014, p. 3). These results indicate that in the Canary Islands, about $20 \%$ of the morphologically distinct species are not separated by the barcoding sequences, and conversely, in about an equal 
percent of the cases cryptic diversity not discernable morphologically was detected with the sequences. It is interesting and perhaps a bit surprising that molecular differences were found among morphologically indistinguishable (at least with available data, and pending further study) plants in about the same frequency as were the lack of molecular differences among morphologically separable species. This suggests the value of multiple approaches for detecting cryptic diversity in island archipelagos; many factors could account for these differences, and they will be summarized below.

Pillon et al. (2013) showed that DNA barcoding with nuclear and plastid sequences in the two genera Clermontia (Campanulaceae) and Cyrtandra (Gesneriaceae) in Hawaii were more effective for distinguishing species on the oldest island compared to identifying species on younger islands. Although nuclear markers were more variable than plastid loci, their longer coalescence times limited their utility as reliable barcodes. The results from several studies from different archipelagos suggest that DNA barcodes when used by themselves have certain shortcomings that limit their utility for identifying species and cryptic diversity in island lineages. However, when used in concert with other data such as morphology and field studies, barcodes may be of value. A new approach to DNA barcoding will be described later in the discussion of future studies.

The use of phylogenetic relationships, often based on DNA sequence data, has been discussed and debated in delimiting species and as guides for conserving biodiversity (e.g., Agapow et al., 2004; Diniz-Filho et al., 2013; Winter et al., 2013; Faith, 2016; Lean and Maclaurin, 2016; Pellens and Grandcolas, 2016a,b; Pellens et al., 2016). This is a complex topic, with various views held on the most appropriate way to assess and conserve phylogenetic diversity (e.g., papers in Pellens and Grandcolas, 2016a). The definition of phylogenetic diversity may vary, but in the most general sense it refers to differences among organisms resulting from their evolutionary history, with the diversity contained within a phylogeny (Pellens and Grandcolas, 2016b). For those who favor using phylogenetic diversity as a conservation guideline, the basic idea is that it is important to conserve the widest range of diversity in terms of traits generated by evolution within a species or within lineages consisting of two or more taxa.

While DNA barcoding focuses primarily on distinguishing species or populations rather than using the data to infer relationships, Hajibabaei et al. (2007) argue that barcoding could be helpful by suggesting taxa (or variants?) that should be included in phylogenetic studies. Regardless of debates on the use of phylogenetic diversity for informing conservation planning in island lineages, two limitations of the approach in conservation have been particularly prevalent. In earlier studies, limited sampling of populations within species (Sang et al., 1994, 1995) was a shortcoming, and the inability to obtain high resolution of relationships using DNA sequence data is a recurring problem (Sang et al., 1994; Kim et al., 1996, 2007; Francisco-Ortega et al., 1997; Gruenstaeudl et al., 2013; Jones et al., 2014). In addition to sampling of populations of each species, especially for geographically widespread and ecologically diverse species, it is critical that populations differing in even the most subtle characters be sampled; equally critical is sampling populations on a variety of substrates.

\section{Hybridization: loss of diversity or generation of cryptic diversity?}

The foregoing discussion focused on divergence and speciation in island plants; attention is now focused on hybridization, especially gene exchange between species. Allendorf et al. (2001, p. 613) commented on the "difficult set of problems" that hybridization presents for conservation biologists. More recently, Wayne and Shaffer (2016) discuss the issues with the legal protection for the products of hybridization, and refer to the "nuances of hybridization as a conservation problem." These problems are particularly relevant for plants on oceanic islands, and plant systematists can contribute to addressing issues of hybridization and conservation. In the present discussion, only hybridization between endemic/native species will be considered; hybridization between native and alien species is an important issue in conservation of island plants (Daehler and Carino, 2001; Knope et al., 2013; Preston and Pearman, 2015) but this complex topic will not be included herein.

Obviously, the first step in addressing issues of hybridization in oceanic lineages is to document that plants are of hybrid origin. Traditionally, the evidence for hybridization has come from morphological data, with intermediacy in morphological characters used to infer hybridization (Anderson, 1953; Rieseberg and Ellstrand, 1993; Soltis and Soltis, 2009). Henderson (2006) presented a useful overview of methods employed for the analysis of morphological data, several of which have been applied in studies of interspecific hybridization in island plants (Borgen, 1976; Brochmann et al., 2000; Nielsen et al., 2003). A variety of molecular markers, including those discussed above, have been used to document hybridization (Twyford and Ennos, 2012). The most effective markers are those that are diagnostic for each of the parental species, that is, they have mutually exclusive alleles or markers. 
Finding species specific markers may be a challenge for congeneric species in oceanic islands because, as noted above, they may not be divergent at commonly-employed molecular markers. However, because species in oceanic islands are often divergent morphologically, the identification of hybrids is usually not a formidable challenge (Borgen, 1996; Brochmann et al., 2000; Nielsen et al., 2003). The challenge usually is not just detecting hybridization, but rather determining the "kind" of hybrids they are, e.g., first generation, advanced generation, or backcrosses to one or both parents (Twyford and Ennos, 2012). This topic will be considered later.

Several aspects of island plants contribute to the occurrence of interspecific hybrids (Bacon et al., 2012; Rieseberg pp. 375376 in Allendorf et al., 2013). First, synthetic crosses have shown that morphologically distinct populations recognized as species or subspecies are commonly cross compatible and their $\mathrm{F}_{1}$ hybrids are viable and fertile. Examples from Hawaii include Bidens (Gillett and Lim, 1970) and Tetramolopium (Lowrey, 1986), both members of Asteraceae, and Wikstroemia (Thymelaeaceae, Mayer, 1991). Fertile interspecific $\mathrm{F}_{1}$ hybrids have also been synthesized in the genus Scalesia (Asteraceae) in the Galápagos (Lindhardt et al., 2009) and Argyranthemum in the Macaronesian archipelagos (Brochmann et al., 2000; reviewed in Francisco-Ortega et al., 1997).

Field observations by plant systematists can provide a first assessment of the potential for hybridization. Although species in island lineages often occupy different habitats, they are nonetheless in close spatial proximity and may come into contact from disturbances caused by the direct and indirect impacts of human activities, and natural phenomena such as volcanic activity, landslides and erosion (Stuessy et al., 1998a and others). In addition to increasing the potential for interspecific gene flow, disturbances may also provide habitats that facilitate the establishment and success of hybrids because hybrids may be at a competitive advantage with their parents in the disturbed habitats as opposed to being at a selective disadvantage in the parental habitats. Anderson (1948) referred to this as "hybridization of the habitat". With the increasing human activity on islands, especially those such as the Canary Islands, which have about 1.6 million inhabitants and perhaps ten million tourists annually (Francisco-Ortega et al., 2000), additional disturbances will occur (van Hengstum et al., 2012). Identifying human-mediated disturbances as they develop on oceanic islands and assessing the potential impact they could have on the spatial distances between congeneric species are important activities of plant systematists because they know the floras of islands and can determine which species could be affected. Several examples from the genus Argyranthemum
(Asteraceae) in the Canary Islands show that activities such as clearing land for farming, deforestation, and tunnel building have brought together different combinations of species and resulted in hybridization (Borgen, 1976; Brochmann et al., 2000; Fjellheim et al., 2009). Other examples of naturally occurring interspecific hybrids in oceanic islands include, among many others: Hawaiian groups such as Scaevola (Goodeniaceae; Gillett, 1966; Howarth and Baum, 2005) and Scalesia (Asteraceae) in the Galápagos Islands (Lindhardt et al., 2009). A third factor that could promote hybridization between species in an island setting is unspecialized pollinators that do not discriminate between species, thus effecting interspecific pollen transfer (Anderson et al., 2001; Bernardello et al., 2001; Crawford et al., 2011). Members of family Asteraceae are common and prominent examples of plants with unspecialized pollinators (Ellis and Johnson, 2009; Horsburgh et al., 2011).

Several easily observable traits, in addition to habitat differences, could reduce gene flow between species. Selfcompatible and highly self-pollinating (see above) species, which are common in island lineages (cf. McMullen, 1987, 1990), would experience reduced frequency of hybridization (Martin and Willis, 2007; Wright et al., 2013) because they typically have small, rather inconspicuous flowers and very high self seed set (Ornduff, 1969). These species produce much less pollen and attract fewer pollinators, both of which reduce the potential for outcrossing, and result in fewer hybrids than would occur between highly outcrossing species (Wolf et al., 2001; Brys et al., 2013). Minimal or no overlap in flowering time between two congeneric species occurring in close spatial occurrence would reduce gene flow, but change in local conditions in any given year, such as difference in precipitation patterns, could alter flowering times. Demonstration of high cross-incompatibility in experimental crosses between species would likewise suggest low likelihood of the production and establishment of hybrids. Extensive and sustained field studies by trained plant systematists who know the floras of islands are critical to assessing the potential for hybridization between congeneric endemic species.

Given that hybridization may occur in island floras, the reasons that it produces a "difficult set of problems" for plant conservation are the several potential outcomes from the process (Arnold, 1997; Arnold and Martin, 2010; Abbott et al., 2013; Björklund, 2013; Yakimowski and Rieseberg, 2014). The outcomes could include the production of either vigorous and fertile hybrids or sub-vital and/or highly sterile hybrid plants. Hybridization could affect the introgression of traits from one species into another or the establishment of stable 
independent lineages that may be recognized as distinct species. Contemporary debate and discussion center on the most common outcomes of hybridization and the feasibility of obtaining data that would increase the success in predicting the results of hybridization in a given instance (Börklund, 2013; Butlin and Ritchie, 2013; Seehausen, 2013). Since hybridization could either enhance or diminish plant biodiversity on oceanic islands, with the extremes being the extinction of species or the origin of new species, any insights into the dynamics of hybridization would be of considerable value for formulating conservation strategies.

The production of interspecific hybrids may threaten the parental species, particularly if one or both are rare and composed of a few small populations, a situation commonly encountered on islands (e.g., Levin et al., 1996; Stuessy et al., 1998b; Francisco-Ortega et al., 2000). The basic threat stems from the production of hybrid seed, which causes a reduction in seed of each of the parental species (Levin et al., 1996). If reciprocal crosses between two species produce similar levels of seed, the rarer species will be at a disadvantage since it will sire a higher percentage of hybrid seed because there are more members of the other species than the same species with which it can mate (Fowler and Levin, 1984). Weaker barriers to gene flow, as often occurs between island congeners, will further promote increased hybridization, placing the rarer species at a greater disadvantage (Levin et al., 1996). An increase in hybrid seed production at the expense of the parental species and the decrease in conspecific seed may result in the extinction of one (the rarer species) or both of the parental populations (Levin et al., 1996). If the fitness of the hybrids equals or exceeds that of the parents in the habitats where one or both parents occur, they will compete with their parents, and limit parental capacity for replacement (Levin et al., 1996).

Fertile hybrids of moderate to high fitness may cause the extinction of a rarer parental species by genetic assimilation when they backcross to one or both parental species. The more abundant parental species, of course, will cross more frequently with the hybrids, resulting in the hybrids more closely resembling that parent, and through generations characters typical of the rarer species will be lost. The culmination of this process would be the extinction of the rarer species as it existed prior to hybridization. If, in contrast to fit hybrids, hybridization produces nonviable seed or progeny of lower fitness, there is a risk of extinction but it is through the process of gametic wastage (Daehler and Carino, 2001).

In sharp contrast to hybridization having a negative impact on biological diversity in oceanic islands, it may also enhance biodiversity, and conservation measures would differ from those employed when available data suggest that hybridization would have a negative effect. In broadest terms, hybridization may enhance diversity in two ways, one being through increasing genetic variation (Seehausen, 2013) within a species via gene flow from another species, that is, via introgression. This is often facilitated by the presence of a hybrid zone, which may be stable and occurs when there is no open habitat for the hybrids. Repeated backcrossing from hybrids to one of the parents in a hybrid zone may facilitate the introgression of adaptive traits. A second way in which diversity could be enhanced by hybridization is through the formation of stabilized hybrid populations distinct from their parents (but at the same ploidy level). The hybrids may occupy habitats where neither parent occurs and be recognized as homploid hybrid species (Yakimowski and Rieseberg, 2014). Schumer et al. (2014) suggested that in some instances the criteria applied for recognizing homoploid species have not been adequate, and they recommended three basic criteria for the recognition of a homoploid hybrid species. The criteria include demonstrating past hybridization between two species (that is, the plants under study are of hybrid origin), showing that the hybrids are reproductively isolated from the parental species, and providing evidence showing that reproductive isolation between hybrids and parents was the result of hybridization. These are rather stringent criteria, and the review by Schumer et al. (2014) shows that the most commonly employed criterion in plants is genetic evidence, the second most common is isolation between parent and hybrid, and the third is evidence that hybridization produced the isolation of the hybrids from their parents. The Schumer et al. (2014) review revealed that only three studies in plants used all three criteria to document homoploid hybrid speciation. Whether the paucity of reports of homoploid hybrid speciation in plants (which is still greater than reports for animals) is a reflection of the rarity of the process in nature or the difficulty of providing convincing evidence using one or more of the three criteria, or both, remains a matter of speculation (Mallet, 2007; Schumer et al., 2014; Yakimowski and Rieseberg, 2014).

Howarth and Baum (2005) suggested that homoploid hybrid species could be more common on oceanic islands than in flowering plants in general, and there are several reasons for this. As mentioned above, congeneric species in a number of insular lineages have been shown to be cross compatible and interfertile, and disturbance may serve both to bring species into contact and provide habitats for hybrid species. Reports of homoploid hybrid species from islands include one or more species of Argyranthemum in the Canary Islands (Brochmann et al., 2000; Borgen et al., 2003; Fjellheim et al., 2009) and 
two species of Scaevola (Goodeniaceae) in the Hawaiian Archipelago (Howarth and Baum, 2005). In the Canaries, the two Argyranthemum parental species of the presumed hybrid species have been brought into contact by the effects of human disturbance, and the hybrid species grow at elevations intermediate between the parents (Brochmann et al., 2000). In Hawaii, one of the hybrid Scaevola species occurs on a recent lava flow and the other is found in wetter forests at higher elevations than its presumed parents (Howarth and Baum, 2005).

The extensive studies of Darwin's finches in the Galapagos Islands by B. R. and P. R. Grant (B. R. Grant and P. R. Grant, 2008; P. R. Grant and B. R. Grant, 2006, 2014) provide remarkable insights into how the implications of hybridization events may vary over a matter of decades. Whether hybridization results in the merging of lineages or produces stabilized lineages depends heavily on selection by the external environment. These alternative outcomes of hybridization are feasible in the stages of radiations before internal barriers to gene flow have evolved (B. R. Grant and P. R. Grant, 2008). To our knowledge no comparable examples have been elucidated for island plants, but there is no reason to believe that they do not exist. As discussed above, oceanic plant lineages often lack intrinsic barriers to gene flow via crossincompatibility and hybrid sterility, which would permit the kind of dynamic situation documented in the finches. The changing landscapes on oceanic islands provide differing selection on hybrids that could either favor or select against hybrids. In particular, and as noted above, the creation of novel or disturbed habitats could provide habitats for hybrids in which they are not competing with the parental species. The basic problem from a conservation perspective is being able to predict with some confidence whether, in any given situation, the outcome of hybridization will enhance or diminish plant biodiversity in oceanic archipelagos, and indeed the situation may change over time. Thus, while there are no hard and fast rules for assessing the conservation implications of hybridization in oceanic archipelagos, careful monitoring of habitats and observations of the morphology of plants growing on the "new" habitats are critical to conservation efforts.

\section{Future studies}

Historically, plant systematics has incorporated data from new methodologies e.g., chromosomes and cytogenetics, secondary chemistry, enzyme electrophoresis, and DNA sequencing (Stuessy et al., 2001). The most recent technological/methodological approaches filtering down to plant systematics have been referred to as next generation sequencing (NGS). Genomic data, which include many markers covering much of the genome, are increasingly providing basic information for studying the patterns and processes of plant evolution, e.g., speciation (Seehausen et al., 2014) as well as having important implications for plant conservation (Primmer, 2009; Ouborg et al., 2010; Lemmon and Lemmon, 2013; Andrews et al., 2016). Some of the presently employed and potential applications of NGS for the studies of insular plants will be discussed but it will be argued, that even though new technologies provide refined insights into the pattern and process of plant evolution on oceanic islands, the input from plant systematists will likewise enhance the value of the genomic data.

As mentioned above, resolution of phylogenetic relationships in island lineages using DNA sequence data has been limited by the lack of variation in the sequences widely used in plant systematics. One important application of NGS is for generating phylogenetic hypotheses in plants (Eaton and Ree, 2013; Lemmon and Lemmon, 2013; Hipp et al., 2014; Hörandl and Appelhans, 2015; Andrews et al., 2016). It seems clear that these new methods will increasingly provide massive amounts of useful data for higher resolution of relationships in island lineages than was achieved with Sanger sequencing of one or a few DNA regions. The challenge has shifted from the collection of massive amounts of data obtainable to how best to process and analyze the data (Edgar, 2010; Eaton, 2014; Andrews et al., 2016).

As far as we are aware, NGS has been used for phylogenetic reconstruction in only one island plant lineage, namely the genus Tolpis (Asteraceae) in the Macaronesian archipelagos (Mort et al., 2015). Although population-level sampling in Tolpis has thus far been somewhat limited, the results indicate that resolution is much higher than achieved previously using sequences commonly employed in systematic studies (Gruenstaeudl et al., 2013). Clades not resolved in prior studies show that there has been divergence and speciation within islands as well as interisland dispersal and speciation (allopatric speciation). In terms of being informative for the conservation of phylogenetic biodiversity (discussed above), the phylogeny of Mort et al. (2015) is of greater value than an earlier phylogeny for Tolpis (Gruenstaeudl et al., 2013) based on Sanger sequencing. The Mort et al. (2015) phylogeny also resolves with strong support cryptic diversity in the form of two entities that had been designated as sp. nov. in earlier publications based on several lines of evidence. In addition, two other described species that have been recognized by some but not all workers in the Canary Islands (Crawford et al., 
2009) were resolved as distinct clades. These preliminary results are encouraging because they show the potential of NSG data for resolving and identifying cryptic diversity heretofore unresolved by other molecular methods. It seems likely that the increased use of NSG data, combined with larger population sampling than was usually done in earlier molecular phylogenetic studies (see discussion by Jones et al., 2014) will provide finer and finer resolution, including the revelation of much heretofore unrecognized cryptic diversity. As discussed above, documenting that one or more populations are distinguished by molecular markers does not provide strong evidence for formal taxonomic recognition. Instead, the molecular data call attention to the necessity of input from plant taxonomists to provide additional biological information before more definitive taxonomic judgments are made. With ever-finer resolution in phylogenies, the greater will be the need for basic systematic/taxonomic/biological data. Several good examples of using molecular markers in combination with other biological data to assess genetic diversity in rare plants and to inform conservation decisions include Olfelt et al. (2001) and Silva et al. (2015).

DNA barcoding using plastid DNA sequences and ITS nuclear sequences was discussed earlier, with the general results that short sequences may not contain sufficient variation at the population and species levels. More recently, NGS has been used for barcoding. This approach, which has been called ultra-barcoding or extended barcoding (Coissac et al., 2016) and the NGS method used has been designated as "genome skimming" (Kane et al., 2012; Straub et al., 2012; Dodsworth, 2015; Li et al., 2015; Pompanon and Samadi, 2015). The basic idea is that instead of using one or a combination of short sequences for standard barcoding, genome wide data encompassing kilobases of data are employed, thus the term ultra-barcoding. Even if short sequences of plastid DNA may show little variation, especially at lower taxonomic levels, having massive amounts of sequence data will provide sufficient variation for barcoding (e.g., Kane et al., 2012). Next generation sequencing technologies (sometime called massively parallel sequencing) involves sequencing the same bases many times, and this depth of coverage is important to the use of NGS data (Steele and Pires, 2011; Straub et al., 2012). Plastid and mitochondrial genomes are present in many copies in plants, as are nuclear ITS sequences. Since the depth of sequencing increases in proportion to the copy number, shallow sequencing will result in greater depth than would be possible for single or low copy sequences, hence the term genome skimming.

To our knowledge, ultra-barcoding has not been applied to island plants; at first glance, it would appear that the approach offers considerable potential, given the limitations of using standard short sequences as barcodes. It may well be that combination of ultra- and standard barcoding approaches can be used (Li et al, 2015; Coissac et al., 2016). There are many issues involved in the actual implementation of genome skimming for ultra-barcoding, and a general appreciation of practical aspects such as time, cost and expertise may be gained by reading several thoughtful short reviews (e.g., Dodsworth, 2015; Li et al., 2015; Coissac et al, 2016).

Molecular markers that have been used to assess genetic diversity within and differentiation among populations of insular species, to assist in characterizing new species, to infer the patterns of dispersal, and to infer parameters of reproductive biology such as mating system (levels of selfing and outcrossing in natural populations) are generally viewed as neutral or near neutral (Ouborg et al., 2010; Kirk and Freeland, 2011). It is indisputable that these markers have proven valuable in conservation efforts. However, they are limited in other respects, an important one being that they are not the basis of adaptive traits that impact the survival of organisms over time, and especially they do not facilitate the adaptation of populations to changes in their environment (Primmer, 2009; Ouborg et al., 2010; Kirk and Freeland, 2011). Gaining insight into the genetic architecture of potentially adaptive traits and further establishing the actual genetic basis of the traits are not trivial tasks, to say the least (Pardo-Diaz et al., 2015) and will be discussed here only briefly. However, it is important to note that even the most sophisticated genomic studies will require the input of plant systematists/ecologists in order to gain insights into the genetic basis of adaptive traits (Anderson et al., 2011; Savolainen et al., 2013; de Villemereuil, 2015).

Many island lineages may be ideal systems for the types of ambitious studies mentioned above because there is often a remarkable diversity of phenotypes occurring in a diverse array of habitats (Carlquist 1974), with notable examples such as the silversword alliance (Baldwin, 2003) and lobeliads (Givnish et al., 2009) of Hawaii, Echium in Macaronesian archipelagos (Bramwell, 1972; Böhle et al., 1996; Romeiras et al., 2011) and Dendroseris in the Robinson Crusoe archipelago (Sanders et al., 1987). Givnish et al. (2009) provide a list and synopsis of several other notable island radiations. The association between distinct habitats and different phenotypes that may be observed over a short distance on an island leads to the hypothesis that phenotypes are adapted to the habitats where they are found to the exclusion of other phenotypes. Indeed, island lineages are often cited as examples of adaptive radiations (Gillespie, 2009; Soulebeau et al., 2015). Systematists familiar 
with the oceanic floras from extensive, sustained field studies are the most likely to note, in addition to obvious phenotypic differences, subtle variation associated with different habitats (Santiago and Kim, 2009; García-Verdugo et al., 2013). These observations could set the stage for such things as common garden and reciprocal transplant studies to ascertain whether plants with the traits of interest maintain those traits in a common environment and have higher fitness in their native habitats, respectively. The studies on the Hawaiian lobeliads by Givnish and colleagues (e.g., Givnish et al., 2004; Montgomery and Givnish, 2008; Givnish and Montgomery, 2014) included field and common garden studies, the results of which indicated that species were adapted to their native habitats in several traits. In addition to the field and common garden studies of lobeliads, there have been additional investigations of other insular lineages from different archipelagos (e.g., Dunbar-Co et al., 2009; Santiago and Kim, 2009; García-Verdugo et al., 2013) showing an association between traits and plant performance, and suggesting the adaptive nature of the phenotypic diversity seen in natural populations.

Once there is evidence that contrasting traits seen in nature are likely adaptive in the habitats where they occur, studies of the genetic basis of the trait may be initiated. This is an onerous task at best and general descriptions of the approaches and the challenges in elucidating at the finest genetic scale adaptive phenotypic traits may be found in several brief, lucid reviews (Stinchbombe and Hoekstra, 2008; Anderson et al., 2011; Savolainen et al., 2013; Pardo-Diaz et al., 2015). The goal of such studies would be to test whether plants with the allele of a gene of interest (a candidate gene) have higher fitness, preferably in natural populations, than plants with alternative alleles. One noteworthy example of gaining insight into the genetic basis of a phenotypic traits in plants comes from populations of Arabidopsis lyrata growing on serpentine and nonserpentine soils (Turner et al., 2010). Turner et al. (2010) sequenced three candidate genes, which were involved in heavy metal detoxification, and calcium and magnesium transport, and their known functions plausible for occurrence on the harsh substrates such as serpentine. The conservation implications of studies of the genetic architecture and basis of adaptive traits are apparent when considering issues such as conservation of ecologically important variation within species, especially the potential to adapt to habitat changes, as may occur in oceanic archipelagos (Carracedo et al, 2011; Weigelt et al., 2016)

Next generation sequencing data can contribute much to studies of hybridization. Twyford and Ennos (2012) suggested that data from NGS technologies could contribute to three important aspects of natural hybridization, including the spatial/ temporal dynamics of hybrid zones, the consequences of the introgression of particular regions or loci into the genetic background of another species, and the formation and stabilization of new species. With regard to the study of these basic issues, two quotations from García-Verdugo et al. (2013) argue for the suitability of island plants for studying hybridization: "Oceanic islands provide an ideal scenario for testing future hypotheses on the ecological role of hybridization in lineage diversification" (García-Verdugo et al., 2013, p. 756); and "The proliferation of molecular-based studies is providing incessant evidence for the occurrence of hybridization events in island radiations, but if we rely solely on this approach, we will fail to fully understand the interplay between ecological and evolutionary processes creating such an unusual degree of variation within particular lineages." (García-Verdugo et al., 2013 , p. 757). Island species are particularly good systems for inferring the temporal aspect of interspecific hybridization because in many cases natural and human-mediated disturbances, which often facilitate hybridization, can be dated (e.g., Borgen, 1976; Carracedo, 2011; van Hengstum et al., 2012). The persistent problem for continental plants of whether shared alleles and morphological intermediacy between species is the result of hybridization or shared ancestral polymorphisms (Twyford and Ennos, 2012; Mallet et al., 2016) is rarely an issue with island plants because, as the plants in question are typically on sites of younger known ages, whereas the two "pure" parental species are distinct over most of their ranges.

There can be little doubt that future investigations of hybridization should focus on long-term studies on islands. There have been no such studies of plants, and of very few from animals. As mentioned above, the classical, multifaceted, studies of B. R. and P. R. Grant (B. R. Grant and P. R. Grant, 2008; P. R. Grant and B. R. Grant, 2006, 2014) carried out over generations, show how the results of hybridization can fluctuate over ecological time. There is the potential for similar kinds of studies in island plants; a specific example will be given. Several species in the genus Argyranthemum (mentioned above) are known to hybridize in different islands in the Canarian archipelago (Borgen, 1976; Borgen et al., 2003; Brochmann, 1984; Brochmann et al., 2000: Francisco-Ortega et al., 1997; Fjellheim et al., 2009). Particularly interesting is hybridization between the species Argyranthemum frutescens (two subspecies involved) and one subspecies of $A$. broussonetii in the Anaga region of Tenerife Island in the Canaries. The former species is coastal and xerophytic, typically occurring below $100 \mathrm{~m}$ above sea level (asl). This species has a tendency to become somewhat weedy and may 
occur at higher altitudes. By contrast, A. broussonetii occurs in the humid laurel forest zone at 550 to $1000 \mathrm{~m}$ asl. Several of the larger hybrid populations (hundreds of plants) have been named taxonomically as $A$. lemsii and $A$. sundingii, and they occur at intermediate altitudes of 150 to $450 \mathrm{~m}$ asl in habitats that vary from semi-arid to humid (Brochmann et al., 2000; Borgen et al., 2003; Fjellheim et al., 2009). Fjellheim et al. (2009) suggested that more recent establishment of hybrids between the two species may have been facilitated by disturbance such as deforestation and road building, whereas there may also be older hybrid populations that predated the disturbances. In addition to the larger populations, three other very small hybrid populations consisting of one, 20 and 40 hybrid plants at disturbed sites were found (Brochmann et al., 2000) but were not studied. Studies utilizing data from morphology and experimental hybridizations (Brochmann et al., 2000) and various molecular markers (Francisco-Ortega et al., 1997; Fjellheim et al., 2009) raised several interesting questions about the hybrid populations between these two species, the two most basic ones being whether the hybrids should be recognized as one or two species (A. lemsii and A. sundingii), or they should be considered hybrid swarms rather than stabilized hybrids. Brochmann et al. (2000) demonstrated that the $F_{1}$ and $F_{2}$ hybrids resulting from crossing the two parental species are vigorous and highly pollen fertile, indicating that reproductive isolation in nature is the result of spatial/habitat divergence rather than intrinsic barriers to gene flow. Secondly, Brochmann et al. (2000) showed that some $\mathrm{F}_{2}$ hybrids were close morphological matches to naturally occurring hybrids. Interestingly, Brochmann et al. (2000) argued that a population assigned to A. sundingii is a stabilized hybrid because the progeny from plants in the population had no higher morphological variation than the progeny of each of the parental species, and less than was found in synthetic $\mathrm{F}_{2}$ hybrids.

Hybridization between Argyranthemum frutescens and $A$. broussonetii in the Anaga area of Tenerife is a good model system for studying the formation and structure of hybrid zones in an insular setting because of the seemingly multiple origins of hybrids at different locations and likely at different times. The hybrid populations vary in size and are considered to be either small hybrid swarms or stabilized hybrid species. The molecular makers that have been employed in studying hybridization (Francisco-Ortega et al., 1997; Fjellheim et al., 2009) between the two species of Argyranthemum have been of limited value in determining whether the hybrid populations are of single or multiple origins (or even if they were hybrids at all) because there were few, if any, diagnostic markers for each of the parental species. However, Francisco-Ortega et al. (1996b) showed that two hybrid populations had the plastid genomes of different parental species, suggesting that the maternal parents were different in the two populations, and thus are the result of different hybridization events. The use of many more molecular markers generated from NGS technologies would very likely be more informative than markers previously employed (Eaton and Ree, 2013; Paun et al., 2016) in elucidating whether hybrid populations are from the same or different hybridization events. This information would be valuable to subsequent studies of populations because, if they have separate origins, they would represent replicate hybridization experiments, and could be informative for inferring the factors that shape variation and evolution subsequent to hybridization (Harrison and Larson, 2016). In this regard, the studies of Rieseberg and collaborators showed that different hybridization events in the genus Helianthus (e.g., Rieseberg et al., 1999; Buerkle and Rieseberg, 2001) showed similar genomic patterns of hybridization and introgression. The parental species are karyotypically divergent, with the first generation hybrids highly sterile (Heiser, 1947), which suggests that selection for fertility in later generations shapes genomes during hybrid speciation. By contrast, if extrinsic factors such as habitat preference drove divergence and speciation of the parents with minimal intrinsic barriers to gene flow between them, then the results of replicate hybridizations between them would presumably be shaped by the external factors of the hybrid habitat. If this were the case, then different results from replicate hybridization events would be expected depending on the habitats of the hybrids.

In contrast to the parental species of the Helianthus hybrids, the Argyranthemum parents have similar karyotypes with few intrinsic barriers to gene flow, and habitat differences likely are selective factors in the evolution of the hybrid populations (Brochmann et al., 2000; Fjellheim et al., 2009). The results of Brochmann et al. (2000) showed that several hybrid populations of Argyranthemum are distinguishable morphologically, and future systematic/biosystematics studies enlarging on the important investigation of Brochmann et al. (2000) should be carried out. That is, variation in traits in the progeny of natural hybrids, progeny of the parental species and synthetic $F_{2}$ hybrids would be compared. These studies would provide insight into the morphological stabilization of the hybrid populations in comparison to their parents and second generation hybrids. In addition, the application of many molecular markers generated by NGS technology could document whether the hybrid populations in the Anaga region are the results of independent events, and also provide insights into the genetic structure of the hybrid populations (Eaton and 
Ree, 2013; Paun et al., 2016. The frequency of diagnostic species markers in individual hybrid plants could provide insight into whether they are first generation, backcross, or advanced generation hybrids by comparing markers in natural hybrids with those in the synthetic hybrids of known origin and with different morphological traits. Since the hybrid populations occur in areas of altitudinal and humidity variation, the correlation of morphological traits and habitat (soil moisture, sun/shade, etc.) could be informative in elucidating traits under selection in the hybrid habitats. In addition, correlations between markers from NGS technology and habitat/morphology could eventually identify regions of the genome associated with introgressed adapative traits (SuarezGonzalez et al., 2016). Highly integrated studies of these hybrid populations over time would represent a major research undertaking, but the rewards would be considerable, both in basic information and applied aspects. Such studies could detect cryptic diversity generated from hybridization. It may eventually be shown that the conservation of variation generated by hybridization is as important in the overall conservation diversity of island floras as conserving variation resulting from speciation by lineage divergence. However, interpreting the potential impacts of hybridization on the diversity of island floras is a formidable challenge, especially in the changing landscapes of oceanic islands. Plant organismal biologists, including especially plant systematists, have crucial roles to play in future studies aimed at the conservation of the rare and unique floras that have evolved on small, isolated spekcs of rock in the vast oceans.

\section{Acknowledgments}

Research by the authors on the plants of the Juan Fernández archipelago was supported by the United States National Science Foundation and the Austrian Science Fund. We appreciate the invitation from Seung-Chul Kim to contribute this short review.

\section{Literature Cited}

Abbott, R. and 37 other authors. 2013. Hybridization and speciation. Journal of Evolutionary Biology 26: 229-246.

Agapow, P.-M., O. R. P. Bininda-Emons, K. A. Crandall, J. L. Gittleman, G. M. Mace, J. C. Marshall and A. Purvis. 2004. The impact of species concept on biodiversity studies. The Quarterly Review of Biology 79: 161-179.

Allendorf, F. W., R. F. Leary, P. Spruell and J. K. Wenburg. 2001. The problems with hybrids: setting conservation guidelines.
Trends in Ecology and Evolution 16: 613-622.

Allendorf, F. W., G. Luikart and S. N. Aitken. 2013. Conservation and the genetics of populations. $2^{\text {nd }}$ edition. John Wiley \& Sons, Chichester, West Sussex.

Anderson, E. 1948. Hybridization of the habitat. Evolution 2: 1-9. Anderson, E. 1953. Introgressive hybridization. Biological Reviews of the Cambridge Philosophical Society 28: 280307.

Anderson, G. J., G. Bernardello, D. J. Crawford and T. F. Stuessy. 2000a. Reproductive biology of Wahlenbergia (Campanulaceae) endemic to Robinson Crusoe Island (Chile). Plant Systematics and Evolution 223: 109-123.

Anderson, G. J., G. Bernardello, P. Lopez, T. F. Stuessy and D. J. Crawford. 2000b. Dioecy and wind pollination in Pernettya rigida (Ericaceae) of the Juan Fernández Islands. Botanical Journal of the Linnean Society 132: 121-141.

Anderson, G. J., G. Bernardello, T. F Stuessy and D. J. Crawford 2001. Breeding system and pollination of selected plants endemic to Juan Fernández Islands. American Journal of Botany 88: 220-233.

Anderson, G. J., G. Bernardello, M. R. Opel, A. Santos-Guerra and M. Anderson. 2006. Reproductive biology of the dioecious Canary Islands endemic Withania aristata (Solanaceae). American Journal of Botany 93: 1295-1305.

Anderson, J. T., J. H. Willis and T. Mitchell-Olds. 2011. Evolutionary genetics of plant adaptation. Trends in Genetics 27: 258-266.

Andrews, K. R., J. M. Good, M. R. Miller, G. Luikart and P. A. Hohenlohe. 2016. Harnessing the power of RADseq for ecological and evolutionary genomics. Nature Reviews Genetics. doi:10.1038/nrg.2015.28

Archibald, J. K., D. J. Crawford, A. Santos-Guerra and M. E. Mort. 2006. The utility of automated analysis of inter-simple sequence repeat (ISSR) loci for resolving relationships in the Canary Island species of Tolpis (Asteraceae). American Journal of Botany 93: 1154-1162.

Arnold, M. L. 1997. Natural hybridization and evolution. Oxford University Press, New York.

Arnold, M. L. and N. H. Martin. 2010. Hybrid fitness across time and habitats. Trends in Ecology and Evolution 25: 530-536.

Bacon, C. D., M. J. McKenna, M. P. Simmons and W. L. Wagner. 2012. Evaluating multiple criteria for species delimitation: an empirical example using Hawaiian palms (Arecaceae: Pritchardia). BMC Evolutionary Biology 2012, 12: 23 http:// www.biomedcentral.com/1471-2148/12/23

Baldwin, B. G. 2003. Characteristics and diversity of Madiinae. In Tarweeds and silverswords: evolution of the Madiinae (Asteraceae). Carlquist, S., B. G. Baldwin and G. D. Carr (eds.), Mis- 
souri Botanical Garden Press, St. Louis. Pp. 17-52.

Bernardello, G., G. J. Anderson, T. F. Stuessy and D. J. Crawford, 2001. A survey of floral traits, breeding systems, floral visitors, and pollination systems of the angiosperms of the Juan Fernandez Islands (Chile). Botanical Review (Lancaster) 67: 255-308.

Bickford, D., D. J. Lohman, N. S. Sodhi, P. K. L. Ng, R. Meier, K. Winkler, K. K. Ingram and I. Das. 2006. Cryptic species as a window on diversity and conservation. Trends in Ecology and Evolution 22: 148-155.

Björklund, M. 2013. The unpredictable impact of hybridization. Journal of Evolutionary Biology 26: 274-275.

Blaxter, M. L. 2004. The promise of a DNA taxonomy. Philosophical Transactions of the Royal Society B. 359: 669-679.

Böhle, U.-R., H. H. Hilger and W. F. Martin. 1996. Island colonization and evolution of the insular woody habit in Echium L. (Boraginaceae). Proceedings of the National Academy of Sciences, USA 93: 11740-11745.

Bonin, A., D. Ehrich and S. Manel. 2007. Statistical analysis of amplified fragment length polymorphism data: a toolbox for molecular ecologists and evolutionists. Molecular Ecology 16: 3737-3758.

Borgen, L. 1976. Analysis of a hybrid swarm between Argyranthemum adauctum and A. filifolium in the Canary Islands. Norwegian Journal of Botany 23: 121-137.

Borgen, L., I. Leitch and A. Santos-Guerra. 2003. Genome organization in diploid hybrid species of Argyranthemum (Asteraceae) in the Canary Islands. Botanical Journal of the Linnean Society 141: 491-501.

Bramwell, D. 1972. A revision of the genus Echium in Macaronesia. Lagascalia 2: 37-115.

Brauner, S., D. J. Crawford and T. F. Stuessy. 1992. Ribosomal and RAPD variation in the rare plant family Lactoridaceae. American Journal of Botany 79: 1436-1439.

Brochmann, C. 1984. Hybridization and distribution of Argyranthemum coronopifolium (Asteraceae-Anthemideae) in the Canary Islands. Nordic Journal of Botany 4: 729-736.

Brochmann, C., L. Borgen and O. E. Stabbetorp. 2000. Multiple diploid hybrid speciation of the Canary Island endemic Argyranthemum sundingii (Asteraceae). Plant Systematics and Evolution 220: 77-92.

Brys, R., A. Vanden Broeck, J. Mergeay and H. Jacquemyn. 2013. The contribution of mating system variation to reproductive isolation in two closely related Centaurium species (Gentianaceae) with a generalized flower morphology. Evolution 68: 1281-1293.

Buerkle, C. A. and L. H. Rieseberg 2001. Low intraspecific variation for genomic isolation between hybridizing sunflower species. Evolution 55: 684-691.

Butlin, R. K. and M. G. Ritchie. 2013. Pulling together or pulling apart: hybridization in theory and practice. Journal of Evolutionary Biology 26: 294-298.

Carlquist, S. 1974. Island biology. Columbia University Press, New York.

Carr, G. D. 1985. Monograph of the Hawaiian Madiinae (Asteraceae): Argyroxiphium, Dubautia, and Wilkesia. Allertonia 4: 1-123.

Carracedo, J. C. 2011. Geología de Canarias. Origen, evolución, edad y volcanismo. Editorial Rueda, E.L., Madrid.

Caujapé-Castells, J., A. Tye, D. J. Crawford, A. Santos-Guerra, A. Sakai, K. Beaver, W. Lobin, F. B. Vincent Florens, M. Moura, R. Jardim, I. Gómes and C. Kueffer. 2010. Conservation of oceanic island floras: present and future global challenges. Perspectives in Plant Ecology, Evolution and Systematics 21:107-129.

Caujapé-Castells, J., A. Marrero-Rodríguez, M. Baccarani-Rosas, J. Naranjo-Suárez, N. Cabrera-García and B. VilchesNavarrete. 2008. Population genetics of the endangered Canarian endemic Atractylis arbuscula (Asteraceae): implications for taxonomy and conservation. Plant Systematics and Evolution 274: 99-109.

CBOL Plant Working Group. 2009. A DNA barcode for land plants. Proceedings of the National Academy of Sciences, USA 106: 12794-12797.

Coissac, E., P. M. Hollingsworth, S. Lavergne and Taberlet. 2016. From barcodes to genomes, extending the concept of DNA barcoding. Molecular Ecology 25: 1423-1428.

Crawford, D. J., T. F. Stuessy and M. Silva O. 1987. Allozyme divergence and the evolution of Dendroseris (Compositae: Lactuceae) on the Juan Fernández Islands. Systematic Botany 12:435-443.

Crawford, D. J., E. Ruiz, T. F. Stuessy, E. Tepe, P. Aqeveque, F. Gonzalez, R. J. Jensen, G. J. Anderson, G. Bernardello, M. Baeza, U. Swenson and M. Silva O. 2001. Allozyme diversity in the endemic flowering plant species of the Juan Fernández Archipelago, Chile: ecological and historical factors with implications for conservation. American Journal of Botany 88 : 2195-2201.

Crawford, D. J., M. Tago-Nakazawa, T. F. Stuessy, G. J. Anderson, G. Bernardello, E. Ruiz, R. J. Jensen, M. Baeza, A. D. Wolfe and M. Silva O. 2001. Intersimple sequence repeat (ISSR) variation in Lactoris fernandziana (Lactoridaceae), a rare endemic of the Juan Fernández archipelago, Chile. Plant Species Biology 16: 185-192.

Crawford, D. J., J. K. Archibald, M. E. Mort, and A. SantosGuerra. 2009. Pollen fertility of synthetic intra- and interspecific $\mathrm{F}_{1}$ hybrids in Canary Island Tolpis (Asteraceae). 
Plant Systematics and Evolution 279:103-113.

Crawford, D. J., G. J. Anderson and G. Bernardello. 2011. The reproductive biology of island plants. In The biology of island floras. Bramwell, D. and J. Caujapé-Castells (eds.), Cambridge University Press, Cambridge. Pp. 11-36.

Crawford, D. J., M. E. Mort and J. K. Archibald. 2013. Tolpis santosii (Asteraceae: Cichorieae), a new species from La Palma, The Canary Islands. Vierea 41: 163-169.

Crawford, D. J., G. J. Anderson, L. Borges Silva, M. Menezes de Sequeira, M. Moura, A. Santos-Guerra, J. K. Kelly and M. E. Mort. 2015. Breeding systems in Tolpis (Asteraceae) in the Macaronesian islands: the Azores, Madeira and the Canaries. Plant Systematics and Evolution 301: 1981-1993.

Daehler, C. C. and D. A. Carino. 2001. Hybridization between native and alien plants and its consequences. In Biotic homogenization. Lockwood, J. L. and M. McKinnney (eds.), Kluwer, New York. Pp. 81-102.

Danton, P., C. Perrier and G. Martinez de Reyes. 2006. Nouveau catalogue de la flore vasculaire de l'archipel Juan Fernández (Chili) Nuevo catálogo de la flora vascular del Archipiélago Juan Fernández (Chile). Acta Botanica Gallica, 153: 4, 399587, DOI: 10.1080/12538078.2006.10515559

de Joode, D. R. and J. F. Wendel. 1992. Genetic diversity and origin of the Hawaiian Islands cotton, Gossypium tomentosum. American Journal of Botany 79: 1311-1319.

de Queiroz, K. 1998. The general lineage concept of species, species criteria, and the process of speciation: a conceptual unification and terminological recommendations. In Endless forms: species and speciation. Howard, D. J. and S. H. Berlocher (eds.), Oxford University Press, Oxford. Pp. 57-75.

de Villemereuil, R., O. E. Gaggiotti, M. Mouterde and I. Till-Bottraud. 2015. Common garden experiments in the genomic era: new perspectives and opportunities. Heredity 116: 249-254.

Diniz-Filho, J. A. F., R. D. Loyola, P. Raia, A. O. Mooers and L. M. Bini. 2013. Darwinian shortfalls in biodiversity conservation. Trends in Ecology and Evolution 28: 689-695.

Dodsworth, S. 2015. Genome skimming for next-generation biodiversity. Trends in Plant Science 20: 525-527.

Dunbar-Co, S., M. J. Sporck and L. Sack. 2009. Leaf trait diversification and design in seven rare taxa of the Hawaiian Plantago radiation. International Journal of Plant Sciences 170: 61-75.

Eaton, D. A. R. 2014. PyRAD: Assembly of de novo RADseq loci for phylogenetic analyses. Bioinformatics 30: 1844-1849.

Eaton, D. A. R. and R. H. Ree. 2013. Inferring phylogeny and introgression using RADseq data: an example from flowering plants (Pedicularis: Orobanchaceae). Systematic Biology 62: 689-706.
Edgar, R. C. 2010. Search and clustering orders of magnitude faster than BLAST. Bioinformatics 26: 2460-2461.

Ellis, A. G. and S. D. Johnson. 2009. The evolution of floral variation without pollinator shifts in Gorteria diffusa (Asteraceae). American Journal of Botany 96: 793-801.

Faith, D. P. 2016. The pd phylogenetic diversity framework: linking evolutionary history to feature diversity for biodiversity conservation. In Biodiversity conservation and phylogenetic systematics, topics in biodiversity and conservation 14. Pellens, R. and P. Grandcolas (eds.), Springer International Publishing, Gewerbestrasse. Pp. 39-54. doi 10.1007/978-3-319-22461-9_3

Ferreira, M. Z., I. Á. Fernández, R. Jardim and M. M. Sequeira. 2014. Andryala perezii (Asteraceae), a new species from the Canary Islands. Novon 23: 147-156.

Fjellheim, S., M. H. Jogensen, M. Kjos and L. Borgen. 2009. A molecular study of hybridization and homoploid hybrid speciation in Argyranthemum (Asteraceae) on Tenerife, Canary Islands. Botanical Journal of the Linnean Society 159: 19-31.

Fowler, N. L. and D. A. Levin. 1984. Ecological constraints on the establishment of a novel polyploid in competition with its diploid progenitor. American Naturalist 124: 703-711.

Francisco-Ortega, J., D. J. Crawford, A. Santo-Guerra and J. A. Carvalho. 1996a. Isozyme differentiation in the endemic genus Argyranthemum (Asteraceae: Anthemideae) in the Macaronesian Islands. Plant Systematics and Evolution 202: 137-152.

Francisco-Ortega, J., R. K. Jansen and A. Santos-Guerra. 1996b. Chloroplast DNA evidence of colonization, adaptive radiation, and hybridization in the evolution of the Macaronesian flora. Proceedings of the National Academy of Sciences, USA 93: 4085-4090.

Francisco-Ortega, J., D. J. Crawford, A. Santos-Guerra and R. K. Jansen. 1997. Origin and evolution of Argyranthemum (Asteraceae: Anthemideae) in Macaronesia. In Molecular evolution and adaptive radiation. Givnish, T. J. and K. J. Sytsma (eds.), Cambridge Univ. Press, Cambridge. Pp. 407-431.

Francisco-Ortega, J., A. Santos-Guerra, S.-C. Kim and D. J. Crawford. 2000. Plant genetic diversity in the Canary Islands: a conservation perspective. American Journal of Botany 87: 909-919.

Freeland, J. R., H. Kirk and S. D. Petersen. 2011. Molecular ecology, ed. 2. Wiley-Blackwell, Oxford.

Friar, E. A., J. M. Cruse-Sanders and M. E. McGlaughlin. 2007. Gene flow in Dubautia arborea and D. ciliolata: the roles of ecology and isolation by distance in maintaining species boundaries despite ongoing hybridization. Molecular Ecology 16: 4028-4038.

Funk, V. A. and K. R. Wood. 2014. Bidens meyeri (Asteraceae, 
Coreopsideae): a new critically endangered species from Rapa, Austral Islands. PhytoKeys 42: 39-47.

García-Verdugo, C., E. Friar and L. S. Santiago. 2013. Ecological role of hybridization in adaptive radiations: a case study in the Dubautia arborea-Dubautia ciliolata (Asteraceae) complex. International Journal of Plant Sciences 174: 749-759.

García-Verdugo, C., M. Sajeva, T. La Mantia, C. Harrouni, F. Msanda, and J. Caujapé-Castells. 2015. Do island plant populations really have lower genetic variation than mainland populations? Effects of selection and distribution range on genetic diversity estimates. Molecular Ecology 24: 726-741.

Gillespie, R. G. 2009. Adaptive radiation. In Encyclopedia of islands. Gillespie, R. G. and D. A. Clague (eds.), University of California Press, Berkeley. Pp. 1-7.

Gillett, G. W. 1966. Hybridization and its taxonomic implications in the Scaevola gaudichaudiana complex of the Hawaiian Islands. Evolution 20: 506-516.

Gillett, G. W. and E. K. S Lim. 1970. An experimental study of the genus Bidens in the Hawaiian Islands. University of California Studies in Botany 56: 1-63.

Givnish, T. J., R. A. Montgomery and G. Goldstein. 2004. Adaptive radiation of photosynthetic physiology in the Hawaiian lobeliads: light regimes, static light responses, and whole-plant compensation points. American Journal of Botany 91: $228-246$.

Givnish, T. J., K. C. Millam, A. R. Mast, T. B. Paterson, T. J. Theim, A. L. Hipp, J. M. Henss, J. F. Smith, K. R. Wood and K. J. Sytsma. 2009. Origin, adaptive radiation and diversification of the Hawaiian lobeliads (Asterales: Campanulaceae). Proceedings of the Royal Society B 276: 407-416.

Givnish, T. J. and R. A. Montgomery. 2014. Common-garden studies on adaptive radiation of photosynthetic physiology among Hawaiian lobeliads. Proceedings of the Royal Society B 281: 20132944. http://dx.doi.org/10.1098/rspb.2013.2944

Grant, B. R. and P. R. Grant. 2008. Fission and fusion of Darwin's finches populations. Philosophical Transactions of the Royal Society B 363: 2821-2829.

Grant, P. R. and B. R. Grant. 2006. Species before speciation is complete. Annals of the Missouri Botanical Garden 93: 94-102.

Grant, P. R. and B. R. Grant. 2014. Synergism of natural selection and introgression in the origin of new species. The American Naturalist 183: 671-681.

Gruenstaeudl, M., A. Santos-Guerra \& R. K. Jansen. 2013. Phylogenetic analyses of Tolpis Adans. (Asteraceae) reveal patterns of adaptive radiation, multiple colonization and interspecific hybridization. Cladistics 29: 416-434.

Hajibabaei, M., G. A. C. Singer, P. D. N. Hebert and D. A. Hickey. 2007. DNA barcoding: how it complements taxonomy, molecular phylogenetics and population genetics. Trends in Genetics 23: 167-171.

Hamrick, J. L. and M. J. W. Godt. 1997. Effects of life history traits on genetic diversity in plant species. In Plant life histories-ecology, phylogeny and evolution. Silvertown, J., M. Fanaco and J. L. Harper (eds.), Cambridge Univ. Press, Cambridge. Pp. 102-118.

Harrison, R. G. and E. L. Larson. 2016. Heterogeneous genome divergence, differential introgression, and the origin and structure of hybrid zones. Molecular Ecology doi: 10.1111/ mec. 13582 .

Hausdorf, B. 2011. Progress toward a general species concept. Evolution 65: 923-931.

Heiser, C. B. 1947. Hybridization between the sunflower species Helianthus annuus and H. petiolaris. Evolution 1: 249-262.

Helenurm, K. and F. R. Ganders. 1985. Adaptive radiation and genetic differentiation in Hawaiian Bidens. Evolution 39: $753-765$.

Henderson, A. 2006. Traditional morphometrics in plant systematics and its role in palm systematics. Botanical Journal of the Linnean Society 151: 103-111.

Hipp, A. L., D. A. R. Eaton, J. E. Cavender-Bares Fitzek, R. Nipper and P. S. Manos. 2014. A framework phylogeny of the American oak clade based on sequenced RAD data. PLoS ONE 9: e93975 10.1371/journal.pone.0093975 .

Hollingsworth, P. M. 2008. DNA barcoding plants in biodiversity hot spots: progress and outstanding questions. Heredity 101: $1-2$.

Hörandl, E. and M. S. Appelhans. eds. 2015. Next generation sequencing in plant systematics. Regnum Vegetabile 158. Koeltz Botanical Books, Oberrelfenberg, Germany.

Horsburgh, M., J. C. Semple and P. G. Kevan. 2011. Relative pollinator effectiveness of insect floral visitors to two sympatric species of wild aster: Symphyotrichum lanceolatum (Willd.) Nesom and S. laterifolium (L.) Löve and Löve (Asteraceae: Astereae). Rhodora 113: 64-86.

Howarth, D. G. and D. A. Baum. 2005. Genealogical evidence of homoploid hybrid speciation in an adaptive radiation of Scaeveola (Goodeniaceae) in the Hawaiian Islands. Evolution 59: 948-961.

Jaén-Molina, R., A. Marrero-Rodríguez, J. A. Reyes-Betancort, A. Santos-Guerra, N. Naranjo-Suárez and J. Caujapé-Castells. 2014. Molecular taxonomic identification in the absence of a 'barcoding gap': a test with the endemic flora of the Canarian oceanic hotspot. Molecular Ecology Resources doi: 10.1111/ 1755-0998.12292

Jones, K. E., J. A. Reyes-Betancort, S. J. Hiscock and M. A. Carine. 2014. Allopatric diversification, multiple habitat shifts, 
and hybridization in the evolution of Pericallis (Asteraceae), a Macaronesian endemic genus. American Journal of Botany 101: 637-651.

Kane, N., S. Sveinsson, H. Dempewolf, J. Y. Yang, D. Zhang, J. M. M. Engels and Q. Cronk. 2012. Ultra-barcoding in cacao (Theobroma spp.; Malvaceae) using whole chloroplast genomes and nuclear ribosomal DNA. American Journal of Botany 99: 320-329.

Kim, S.-C., D. J. Crawford, J. Francisco-Ortega and A. SantosGuerra. 1996. A common origin for woody Sonchus and five related genera in the Macaronesian islands: molecular evidence for extensive radiation. Proceedings of the National Academy of Sciences, USA 93: 7743-7748.

Kim, S.-C., D. J. Crawford, J. Francisco-Ortega and A. SantosGuerra.1999. Adaptive radiation and genetic differentiation in the woody Sonchus alliance (Asteraceae: Sonchinae) in the Canary Islands. Plant Systematics and Evolution 215: 101-118.

Kim, S.-C., C. Lee and J. A. Mejías. 2007. Phylogenetic analysis of chloroplast DNA matK gene and ITS of nrDNA sequences reveals polyphyly of the genus Sonchus and new relationships among the subtribe Sonchinae (Asteraceae: Cichorieae). Molecular Phylogenetics and Evolution 44: 578-597.

Kirk, H. and J. R. Freeland. 2011. Applications and implications of neutral versus non-neutral markers in molecular ecology. International Journal of Molecular Sciences 12: 3966-3988.

Knope, M. L., R. Pender, D. J. Crawford, and A. M. Wieczorek. 2013. Alien congeners are unlikely to hybridize with native Hawaiian Bidens (Asteraceae). American Journal of Botany 100: $1221-1226$.

Kreft, H., W. Jetz, J. Mutke, G. Kier and W. Barthlott. 2008 Global diversity of island floras from a macroecological perspective. Ecology Letters 11: 116-127.

Kress, W. J., K. J. Wurdack, E. A. Zimmer, L. A. Weigt and D. H. Janzen. 2005. Use of DNA barcodes to identify flowering plants. Proceedings of the National Academy of Sciences USA 102: 8369-8374.

Lean, C. and J. Maclaurin. 2016. The value of phylogenetic diversity. In Biodiversity conservation and phylogenetic systematics, topics in biodiversity and conservation 14 . Pellens, R. and P. Grandcolas (eds.), Springer International Publishing, Gewerbestrasse. Pp. 19-37. DOI 10.1007/978-3319-22461-9_3

Lemmon, E. M. and A. R. Lemmon. 2013. High-throughput genomic data in systematics and phylogenetics. Annual Review of Ecology, Evolution and Systematics 44: 99-121.

Levin, D. A. 1996. The evolutionary significance of pseudo-selffertility. American Naturalist 148: 321-332

Levin, D. A., J. Francisco-Ortega and R. K. Jansen. 1996. Hybrid- ization and the extinction of rare plant species. Conservation Biology 10: 10-16.

Li, X., Y. Yang, R. J. Henry, M. Rossetto, Y. Wang and S. Chen. 2015. Plant DNA barcoding: from gene to genome. Biological Reviews of the Cambridge Philosophical Society 90: 157166.

Lindhardt, M. S., M. Philipp, A. Tye and L. R. Nielsen. 2009. Molecular, morphological, and experimental evidence for hybridization between threatened species of the Galapagos endemic genus Scalesia (Asteraceae). International Journal of Plant Sciences 170: 1019-1030.

López-Sepúlveda P., Lowrey, T. K. 1986. A biosystematic revision of Hawaiian Tetramolopium (Compositae: Astereae). Allertonia 4: 203-265.

López-Sepúlveda, P., K. Takayama, J. Greimler, D. J. Crawford, P. Peñailillo, M. Baeza, E. Ruiz, G. Kohl, K. Tremetsberger, A. Gatica, L. Letelier, P. Novoa, J. Novak and T. F. Stuessy. 2014. Progressive migration and anagenesis in Drimys confertifolia of the Juan Fernández Archipelago, Chile. Journal of Plant Research. 128: 73-90. doi:10.1007/s10265-014-0666-7

Lowrey, T. K. 1986. A biosystematic revision of Hawaiian Tetramolopium (Compositae: Astereae). Allertonia 4: 203-265.

Lowrey, T. K. and D. J. Crawford. 1985. Allozyme divergence and evolution in Tetramolopium (Compositae: Astereae) on the Hawaiian Islands. Systematic Botany 10: 64-72.

Mallet, J. 1995. A species definition for the Modern Synthesis. Trends in Ecology and Evolution 10: 294-299.

Mallet, J. 2007. Hybrid speciation. Nature 446: 279-283.

Mallet, J., N. Besansky and M. W. Hahn. 2016. How reticulated are species? Bioessays 38: 140-149.

Martin, N. H. and J. H. Willis. 2007 Ecological divergence associated with mating system causes nearly complete reproductive isolation between sympatric Mimulus species. Evolution 61: 68-82.

Mayden, R. L. 1997. A hierarchy of species concepts: the denouement in the saga of the species problem. In Species: the units of biodiversity. Claridge, M. F., H. A. Dawah and M. R. Wilson (eds.), Chapman and Hall, London. Pp. 381-424.

Mayer, S. S. 1991. Artificial hybridization in Hawaiian Wikstroemia (Thymelaeaceae). American Journal of Botany 78: 122-130.

McMullen, C. K. 1987. Breeding systems of selected Galápagos Islands angiosperms. American Journal of Botany 74: 16941705.

McMullen, C. K. 1990. Reproductive biology of Galápagos Islands angiosperms. In Botanical research and management in Galápagos. Lawesson, J. E., O. Hamann, G. Rogers, G. Reck and H. Ochoa (eds.), vol 32. Monographs in systematic botany 
from the Missouri Botanical Garden, St. Louis, Pp 35-45.

Mejías, J. A. and S.-C. Kim. 2012. Taxonomic treatment of Cichorieae (Asteraceae) endemic to the Juan Fernández and Desventuradas Islands (SE Pacific). Annales Botanici Fennici 49: $171-178$.

Meudt, H. M. and A. C. Clarke. 2007. Almost forgotten or latest practice? AFLP applications, analyses and advances. Trends in Plant Science 12: 106-117.

Montgomery, R. A. and T. J. Givnish. 2008. Adaptive radiation of photosynthetic physiology in the Hawaiian lobeliads: dynamic photosynthetic responses. Oecology 155: 455-467.

Mort, M.E., C. P. Randle, J. K. Archibald, N. Levsen, T. R. O'Leary, K. Topalov, C. Wiegand and D. J. Crawford. 2007. Inferring phylogeny at low taxonomic levels: Utility of rapidly evolving cpDNA and nuclear ITS loci. American Journal of Botany 94: 173-183.

Mort, M. E., D. J. Crawford, J. K. Archibald, T. R. O'Leary and A. Santos-Guerra. 2010. Plant DNA barcoding: a test using Macaronesian taxa of Tolpis (Asteraceae). Taxon 59: 581-587.

Mort, M. E., D. J. Crawford, J. K. Kelly, A. Santos-Guerra, M. Menezes de Sequeira, M. Moura and J. Caujapé-Castells. 2015. Mulitplexed-shotgun-genotyping data resolve phylogeny within a very recently derived insular lineage. American Journal of Botany 102: 634-641.

Nielsen, L., H. S. Siegismund and M. Philipp. 2003. Partial selfincompatibility in the polyploid endemic species Scalesia affinis (Asteraceae) from the Galápagos: remnants of a selfincompatibility system? Botanical Journal of the Linnean Society 142: 93-101.

Nybom, H. 2004. Comparison of different nuclear DNA markers for estimating intraspecific genetic diversity in plants. Molecular Ecology 13: 1143-1155.

Olfelt, J. P., G. R. Furnier and J. J. Luby. 2001. What data determine whether a plant taxon is distinct enough to merit legal protection? A case study of Sedum integrifolium (Crassulaceae). American Journal of Botany 88: 401-410.

Ornduff, R. 1969. Reproductive biology in relation to systematics. Taxon 18:121-133.

Otto, R., R. J. Whittaker, M. von Gaisberg, C. Stierstorfer, A. Naranjo-Cigala, M. J. Steinbauer, M. K. Borregaard, J. R. Arevalo, V. Garzon-Machado, M. del Arco and J. M. Fernandez-Palacios. 2016. Transferring and implementing the general dynamic model of oceanic island biogeography at the scale of island fragments: the roles of geological age and topography in plant diversification in the Canaries. Journal of Biogeography. doi:10.1111/jbi.12684

Ouborg, N. J., C. Pertoldi, V. Loeschche, R. K. Bijlsma and P. W. Hedrick. 2010. Conservation genetics in transition to conservation genomics. Trends in Genetics 26: 177-187.

Pannell, J. R. 2015. Evolution of the mating system in colonizing plants. Molecular Ecology 24: 2018-2037.

Pardo-Diaz, C., C. Salazar and C. D. Jiggins. 2015. Towards the identification of the loci of adaptive evolution. Methods in Ecology and Evolution 6: 445-464.

Paun, O., B. Turner, E. Trucchi, J. Munzinger, M. W. Chase and R. Samuel. 2016. Processes driving the adaptive radiation of a tropical tree (Diospyros, Ebenaceae) in New Caledonia, a biodiversity hotspot. Systematic Biology 65: 212-227.

Pellens, P. and P. Grandcolas (eds.). 2016a. Biodiversity Conservation and Phylogenetic Systematics, Topics in Biodiversity and Conservation 14. Springer International Publishing, Gewerbestrasse. DOI 10.1007/978-3-319-22461-9_3

Pellens, P. and P. Grandcolas. 2016b. Phylogenetics and conservation biology: drawing a path into the diversity of life. In Biodiversity conservation and phylogenetic systematics, topics in biodiversity and conservation 14. Pellens, R. and P. Grandcolas (eds.) Springer International Publishing, Gewerbestrasse. Pp. 1-15. DOI 10.1007/978-3-319-22461-9_3

Pellens, R., D. P. Faith and P. Grandcolas. 2016. The future of phylogenetic systematics in conservation biology: linking biodiversity and society. In Biodiversity conservation and phylogenetic systematics, topics in biodiversity and conservation 14. Pellens, R. and P. Grandcolas (eds.) Springer International Publishing, Gewerbestrasse. Pp. 375-383. doi 10.1007/978-3-319-22461-9_3

Pereira, M. J. 2008. Reproductive biology of Vaccinium cylindraceum (Ericaceae), an endemic species of the Azores archipelago. Canadian Journal of Botany 86: 359-366.

Pérez de Paz, J. and J. Caujapé-Castells. 2013. A review of the allozyme data set for the Canarian endemic flora: causes of the high genetic diversity levels and implications for conservation. Annals of Botany 111: 1059-1073. doi:10.1093/aob/mct076

Pillon, Y., J. Johansen, T. Sakishima, S. Chamala, W. B. Barbazuk, E. H. Roalson, D. K Price and E. A. Stacy. 2013. Potential use of low-copy nuclear genes in DNA barcoding: a comparison with plastid genes in two Hawaiian plant radiations. BMC Evolutionary Biology 13:35. http://www.biomedcentral.com/1471-2148/13/35.

Pompanon, F. and S. Samadi. 2015. Next generation sequencing for characterizing biodiversity: promises and challenges. Genetica 143: 133-138.

Preston, C. D. and D. A. Pearman. 2015. Plant hybrids in the wild: evidence from biological recording. Biological Journal of the Linnean Society 115: 555-572.

Primmer, C. R. 2009. From conservation genetics to conservation genomics. Annals of the New York Academy of Sciences 
1162: $357-368$.

Puppo, P. 2015. New species and new combinations in Micromeria (Lamiaceae) from the Canary Islands and Madeira. Phytotaxa 230: 1-21.

Puppo, P., M. Curto, G. Velo-Antón, P. L. Pérez de Paz and H. Meimberg. 2014. The influence of geological history on diversification in insular species: genetic and morphological patterns of Micromeria Benth. (Lamiaceae) in Tenerife (Canary archipelago). Journal of Biogeography 41: 18711882.

Rieseberg, L. H. 2013. Hybridization and the conservation of plants. in Allendorf, F. W., G. Luikart and S. N. Aitken.. Conservation and the Genetics of Populations. $2^{\text {nd }}$ edition. John Wiley \& Sons, Chichester, West Sussex. Pp. 375-376

Rieseberg, L. H. and N. C. Ellstrand. 1993. What can morphological and molecular markers tell us about plant hybridization? Critical Reviews in the Plant Sciences 12: 213241.

Rieseberg, L. H., J. Whitton and K. Gardner. 1999. Hybrid zones and the genetic architecture of a barrier to gene flow between two sunflower species. Genetics 152: 713-727.

Romeiras, M. M., O. S. Paulo, M. C. Duarte, F. Pina-Martins, M. H. Cotrim, M. A. Carine and M. Salomé Pais. 2011. Origin and diversification of the genus Echium (Boraginaceae) in the Cape Verde archipelago. Taxon 60: 1375-1385.

Sanders, R., T. F. Stuessy, C. Martecorena and M. Silva O. 1987. Phytogeography and evolution of Dendroseris and Robinsonia, tree-Compositae of the Juan Fernández Islands. Opera Botanica 92: 195-215.

Sang, T., D. J. Crawford, S. Kim and T. F. Stuessy. 1994. Radiation of the endemic genus Dendroseris (Asteraceae) on the Juan Fernández Islands: evidence from sequences of the ITS region of nuclear ribosomal DNA. American Journal of Botany 81: 1494-1501.

Sang, T., D. J. Crawford and T. F. Stuessy. 1995. ITS sequences and the phylogeny of the genus Robinsonia (Asteraceae). Systematic Botany 20: 55-64.

Santiago, L. S. and S.-C. Kim. 2009. Correlated evolution of leaf shape and physiology in the woody Sonchus alliance (Asteraceae: Sonchinae) in Macaronesia. International Journal of Plant Sciences 170: 83-92.

Savolainen, O., M. Lascoux and J. Merila. 2013. Ecological genomics of local adaptation. Nature Reviews Genetics 14: 807-820.

Schäefer, H., M. Moura, M. G. B. Maciel, L. Silva, F. J. Rumsey and M. A. Carine. 2011. The Linnean shortfall in oceanic island biogeography: a case study in the Azores. Journal of Biogeography 38: 1345-1355.
Schlötterer, C. 2004. The evolution of molecular markers just a matter of fashion? Nature Reviews Genetics 5: 63-69.

Schumer, M., G. G. Rosenthal and P. Andolfatto. 2014. How common is homoploid hybrid speciation? Evolution 68: $1553-1560$.

Seehausen, O. 2013. Conditions when hybridization might predispose populations for adaptive radiation. Journal of Evolutionary Biology 26: 379-281.

Seehausen, O., R. K. Butlin, I. Keller, C. E. Wagner, J. W. Boughman, P. A. Hohenlohe, C. L. Peichel and G.-P. Saetre et al. 2014. Genomics and the origin of species. Nature Reviews Genetics 15: 176-192.

Senterre, B., E. Henriette, I. Larridon, C. Morel and P. Goetghebeur. 2015. Revision of the genus Costularia (Cyperaceae: Schoeneae) for the flora of the Seychelles, including the rediscovery and resurrection of a rare endemic species. Phytotaxa 231: 31-41.

Sherrod, D. R. 2009. Hawaiian Islands, geology. In Encyclopedia of islands. Gillespie, R. G. and D. A. Clague (eds.). University of California Press, Berkeley. Pp. 404-410.

Silva, L., E. F. Dias, J. Sardos, E. B. Azevedo, H. Schäefer and M. Moura. 2015. Towards a more holistic research approach to plant conservation: the case of rare plants on oceanic islands. AoB PLANTS 7: plv066; doi:10.1093/aobpla/plv066

Silva Borges, L., J. Sardos, M. Menezes de Sequeira, L. Silva, D. Crawford and M. Moura. 2016. Understanding intra and interarchipelago population genetic patterns within a recently evolved insular endemic lineage. Plant Systematics and Evolution 302: 367-384.

Slotte, T., K. M. Hazzouri, D. Stern, P. Andolfatto and S. I. Wright. 2012. Genetic architecture and adaptive significance of the selfing syndrome in Capsella. Evolution 66: 1360-1374

Soltis, P. S. and D. E. Soltis. 2009. The role of hybridization in plant speciation. Annual Review of Plant Biology 60: 561-588.

Soulebeau, A., X. Aubriot, M. Gaudeul, G. Rouhan, S. Hennequin, T. Haevermans, J.-Y. Dubuisson and F. Jabbour. 2015. The hypothesis of adaptive radiation in evolutionary biology: hard facts about a hazy concept. Organisms, Diversity and Evolution 15: 747-761.

Steele, P. R. and J. C. Pires. 2011. Biodiversity assessment: Stateof-the-art techniques in phylogenomics and species identification. American Journal of Botany 98: 415-425.

Stinchcombe, J. R. and H. E. Hoekstra. 2008. Combining population genomics and quantitative genetics: finding the genes underlying ecologically important traits. Heredity 100: 158-170.

Straub, S. C. K., M. Parks, K. Weitemier, M. Fishbein, R. C. Cronn and A. Liston. 2012. Navigating the tip of the genomic iceberg: Next generation sequencing for plant systematics. 
American Journal of Botany 99: 349-364.

Stuessy, T. F., U. Swenson, D. J. Crawford, G. Anderson and M. Silva O. 1998a. Plant conservation in the Juan Fernandez Archipelago, Chile. ALISO 16:89-102.

Stuessy, T. F., U. Swenson, C. Marticorena and D. J. Crawford. 1998b. Loss of plant diversity and extinction on Robinson Crusoe Islands, Chile. In Rare, threatened, and endangered floras of Asia and the Pacific Rim. Peng, C.-I. and P. P. Lowry II (eds.), Institute of Botany, Academica Sinica Monograph Series No. 16. Taipei. Pp. 243-257.

Stuessy, T. F., E. Hörandl and V. Mayer (eds). 2001. Plant Systematics: A Half-century of Progress (1950-2000) and Future Challenges. International Association for Plant Taxonomy, Vienna.

Suarez-Gonzales, A., C. A. Hefer, C. Christie, O. Corea, C. Lexer, Q. C. B. Cronk and C. J. Douglas. 2016. Genomic and functional approaches reveal a case of adaptive introgression from Populus balsamifera (balsam poplar) in P. trichocarpa (black cottonwood). Molecular Ecology doi: 10.1111/ mec.13539

Sun, B.-Y., T. F. Stuessy, A. M. Humana, M. Riveros and D. J. Crawford. 1996. Evolution of Rhaphithamnus venustus (Verbenaceae), a gynodioecious hummingbird-pollinated endemic of the Juan Fernandez Islands, Chile. Pacific Science 50: 5565.

Takayama, K., P. López, C. König, G. Kohl, J. Novak and T. Stuessy. 2011. A simple and cost-effective approach for microsatellite isolation in non-model plant species using smallscale 454 pryrosequencing. Taxon 60: 1442-1449.

Takayama, K., P. López Sepúlveda, G. Kohl, J. Novak and T. Stuessy. 2013. Development of microsatellite markers in Robinsonia (Asteraceae) an endemic genus of the Juan Fernández Archipelago, Chile. Conservation Genetics Resources 5: 6367.

Thompson, K. A. and S. G. Newmaster. 2014. Molecular taxonomic tools provide more accurate estimates of species richness at less cost than traditional morphology-based taxonomic practices in a vegetation survey. Biological Conservation 23: 1411-1424.
Turner, T. L., E. C. Bourne, E. J. Von Wettberg, T. T. Hu and S. V. Nuzhdin. 2010. Population resequencing reveals local adaptation of Arabidopsis lyrata to serpentine soils. Nature Genetics 42: 260-263.

Twyford, A. D. and R. A. Ennos. 2012. Next-generation hybridization and introgression. Heredity 108: 179-189.

van Hengstum, T., S. Lachmuth, J. G. B. Oostermeijer, H. J. C. M. den Nijs, P. G. Meirmans and P. H. van Tienderen. 2012. Human-induced hybridization among congeneric endemic plants on Tenerife, Canary Islands. Plant Systematics and Evolution 298: 1119-1131.

Wayne, R. K. and H. B. Shaffer. 2016. Hybridization and endangered species protection in the molecular era. Molecular Ecology. doi: 10.1111/mec.13642

Weigelt, P., M. J. Steinbauer, J. S. Cabral and H. Kreft. 2016. Late Quaternary climate change shapes island biodiversity. Nature 532: 99-102.

Winter, M., V. Devictor and O. Schweiger. 2013. Phylogenetic diversity and nature conservation: where are we? Trends in Ecology and Evolution 28: 199-204.

Witter, M. S. and G. D. Carr. 1988. Adaptive radiation and genetic differentiation in the Hawaiian silversword alliance (Compositae: Madiinae). Evolution 42: 1278-1287.

Wolf, D. E., N. Takebayashi and L. H. Rieseberg. 2001. Predicting risk of extinction through hybridization. Conservation Biology 15: 1039-1053.

Wright, S. I., S. Kalisz and T. Slotte. 2013. Evolutionay consequences of self-fertilization in plants. Proceedings of the Royal Society B 280: 20130133. doi: 10.1098/rspb.2013.0133

Yakimowski, S. B. and L. H. Rieseberg. 2014. The role of homoploid hybridization in evolution: A century of studies synthesizing genetics and ecology. American Journal of Botany 101: 1247-1258.

Zalapa, J. E., H. Cuevas, H. Zhu, S. Steffan, D. Senalik, E. Zeldin, B. McCown, R. Harbut and P. Simon. 2012. Using next-generation sequencing to isolate simple sequence repeat (SSR) loci in the plant sciences. American Journal of Botany 99: 193-208. 